\title{
Evaluation of Selenium, Calcium and Membrane Potential among Breast Cancer Patients in Owerri
}

\author{
Nnodim Johnkennedy ${ }^{1 *}$ Njoku Chukwudi Joseph $^{2}$, Nwaokoro Joakin Chidozie ${ }^{3}$ and Ihionu Chukwudozie A $^{4}$ \\ ${ }^{1}$ Department of Medical Laboratory Science, Imo State University, Nigeria
}

${ }^{2}$ Department of Pharmacology, Niger Delta University Amassoma, Bayelsa State Nigeria

${ }^{3}$ Department of Public Health, Federal University of Technoloy, Owerri, Imo State, Nigeria

${ }^{4}$ Dalzon Medical Diagnostics Limited, Imo State Nigeria

Submission: October 24, 2019; Published: October 29, 2019

*Corresponding author: Nnodim Johnkennedy, Department of Medical Laboratory Science, Faculty of Health Science, Imo State University, Owerri, Nigeria

\section{Abstract}

Background: Breast cancer is the cancer diagnosed in women mostly.

Aim: This study was investigated to evaluate the level of selenium, calcium and membrane potential among breast cancer patients in Owerri.

Material and Method: 38 breast cancer patients and 36 apparently healthy subjects between the ages of 45- 60 years admitted to General Hospital Owerri were selected in this study. Fasting venous blood was collected and was used for the determination of selenium, calcium and membrane potential.

Results: The results obtained revealed that the levels of selenium and membrane potential were significantly decreased in breast cancer patients when compared with the control at $\mathrm{P}<0.05$.

Conclusion: This could probably imply reduction of selenium and cell membrane potential leading to oxidative stress.

Keywords: Selenium; Membrane potential; Breast cancer; Patients

\section{Introduction}

Breast cancer is the type of cancer that forms in the cells of the breasts. It is the commonly cancer diagnosed in women [1]. It can occur in both men and women; but it's far more common in women. It is characterized by the presence of a breast lump or thickening that feels different from the surrounding tissue; differences in the size; shape or appearance of a breast; as well as changes to the skin over the breast; such as dimpling. Other features include a newly inverted nipple; and peeling; scaling; crusting or flaking of the pigmented area of skin surrounding the nipple (areola) or breast skin as well as redness or pitting of the skin over the breast; like the skin of an orange [2]. Breast cancer results when some breast cells begin to grow abnormally. These cells divide more rapidly than healthy cells do and continue to accumulate; forming a lump or mass. Cells metastasize via the breast to lymph nodes or to other parts of the body [3]. It commonly starts with cells in the milk-producing ducts. While some may start in the glandular tissue called lobules or in other cells or tissue within the breast [4]. It has been reported that hormones; lifestyle and environmental factors may affect risk of breast cancer. However; it is not clear why some have no risk factors develop cancer; yet other people with risk factors never do. It's likely that breast cancer is caused by a complex interaction of genetic makeup and environment. Also; membrane potential and calcium dynamics may be affected in breast cancer [5]. This membrane potential could be as a result of disparities in concentration and permeability of important ions across a membrane. Because of the unbalance concentrations of ions across a membrane; the membrane has an electrical charge. Membrane potential is simply the difference in voltage (or electrical potential) between the inside and outside of a cell [6].

In fact; without membrane potentials human life may be highly affected. Truly; living cells maintain a potential difference across their membrane. Owing to unequal concentrations of ions across a membrane; the membrane has an electrical charge. Differences in membrane potential result to action potentials and give cells the ability to send messages around the body [7]. In the light of above; 


\section{Global Journal of Reproductive Medicine}

the action potentials are electrical signals; these signals carry efferent messages to the central nervous system for processing and afferent messages away from the brain to bring about a specific reaction. Several active transports embedded within the cellular membrane results in the formation of membrane potentials; and the universal cellular structure of the lipid bilayer. Membrane potential plays the role of sending messages to and from the central nervous system. It is necessary in cellular biology and displays how cell biology is mainly connected with electrochemistry and physiology [8]. In this study; the level of membrane potential; selenium and calcium in breast cancer patients was determined to provide information for better management and diagnosis.

\section{Material and Methods}

\section{Research design}

A case control study design was conducted in General Hospital Owerri from January 2016 to October 2016.

\section{Subjects}

A total of 38 confirmed breast cancer patients within the ages of 45-60 years attending General Hospital Owerri were involved in the study while 38 apparently healthy non breast cancer within the ages of 45-60 years served as control.

\section{Blood collection}

In all subjects $4 \mathrm{ml}$ of fasting veinous blood was collected into plain and EDTA bottle. The serum was separated by centrifuging the whole blood in wester fuge (model 684) centrifuge at 5;000g for 10 minutes.

\section{Biochemical assay}

The serum calcium was estimated using Randox Kit. The plasma selenium was determined by atomic absorption Spectrophotometric method [9]. While membrane potential was determined by calculation using Nerst Equation.

\section{Statistical analysis}

The results were expressed as mean \pm standard deviation. The statistical evaluation of data was performed by using independent students $\mathrm{t}$ - test. The level of significance was calculated at $\mathrm{p}<0.05$.

\section{Ethical clearance}

Informed consent of the participants was obtained and was conducted in line with the ethical approval of the hospital.

\section{Discussion}

In this study the level of selenium was significantly decreased in breast cancer when compared with the control. This is in line with the work of [10]. The decrease in concentration of Selenium could be linked to oxidative stress in which high level of free radicals is released. Selenium plays an essential role as a cofactor for the reduction of antioxidant enzyme such as glutathione peroxidase; an enzyme which aids react with potentially harmful oxidizing agents in substances. Hence; high level of free radicals generated in cancer may probably result in reduction of selenium [11]. In this study; the membrane potential was significantly reduced in breast cancer patients when compared with the control Table 1. Membrane potentials in cells are determined primarily by three factors: the concentration of ions on the inside and outside of the cell; the permeability of the cell membrane to those ions through specific ion channels; and by the activity of electrogenic pumps. [12]. The change in charge typically occurs due to an influx of sodium ions into a cell; although it can be mediated by an influx of any kind of cation or efflux of any kind of anion. This is consistent with the work of [13]. This means that there is reduction in cell activity in breast cancer patients. This could be associated with high cell depolarization and free radicals' generation as well as increased utilization of ATPase enzyme which is a solute pump that pumps potassium into cells while pumping sodium out of cells; both against their concentration gradients.

Table 1: Selenium, Calcium and Membrane Potential in Breast Cancer Patients and Healthy Control.

\begin{tabular}{|c|c|c|}
\hline Parameters & Control & Breast Cancer \\
\hline Selenium $(\mu / \mathrm{dl})$ & $66.79 \pm 5.8$ & $59.41 \pm 6.2$ \\
\hline Red cell calcium $(\mathrm{mmol} / \mathrm{L})$ & $0.59 \pm 0.05$ & $1.06 \pm 0.17$ \\
\hline Serum calcium $(\mathrm{mmol} / \mathrm{L})$ & $2.03 \pm 0.02$ & $1.81 \pm 0.11$ \\
\hline Membrane Potential(J) & $206.44 \pm 24.00$ & $102.45 \pm 38.82$ \\
\hline
\end{tabular}

*Significantly different from Control at $\mathrm{P}<0.05$. The Levels of Selenium and Membrane Potential were Decreased in Breast Cancer Patients when Compared with the Control at $p<0.05$.

\section{Conclusion}

This reduction of selenium and cell membrane potential in breast cancer could lead to oxidative stress.

\section{References}

1. Nnodim JK, Orji SM, Ihionu CA (2018) Serum tumor necrosis factor alpha and C-reactive protein increase in breast cancer patients Med Sc i 11(4): 233-236.
2. Roxburgh CS, Mc Millan DC (2010) Role of systemic inflammatory response in predicting survival in patients with primary operable cancer. Future Oncol 6: 149-163.

3. Noemi E, Francisco JV (2012) Inflammation and cancer. World J Gastrointest Surg 4(3): 62-72.

4. Travis RC, Balkwill A, Fenson GK, Appleby PN, Reeves GK, et al. (2016) Night shift work and breast cancer incidence: Three prospective studies and meta-analysis of published studies. J Natl Cancer Inst 108(12): 169 . 
5. Mourouti N, Kontogianni MD, Papavagelis C, Panagiotakos DB (2015) Diet and breast cancer: a systematic review. Int J Food Sci Nutr 66(1) $1-42$.

6. Nnodim JK, Nwobodo E, Nwadike C, Edward U, Okorie H (2016) Membrane depolarization in stroke patients Acta Medica Scientia 3(4): 8-10.

7. Nnodim JK, Nsonwu M, Obioma Elemba JE, Nwadike C, Edward U (2016) Decreased Magnesium level and membrane potential of glaucoma patients. Universa Medicina 35(2): 111-115.

8. NnodimJk, Meludu SC, CE Dioka CE, Onah C (2014) Altered Membrane Potential and Electrolyte in Sickle Cell Anemia. Journal of Krishna Institute of Medical Sciences University 3(1): 70-73.
9. Ochei J, Kolhatkar A (2008) Medical Laboratory Science Theory and Practical. ( $7^{\text {th }}$ edn.), McGraw Hill; Noida, pp. 177-187.

10. Boris Pasche (2010) Cancer Genetics (Cancer Treatment and Research). Berlin: Springer p. 19-20.

11. D Souza ND1, Murthy NS, Aras RY (2013) Projection of Cancer Incident Cases for India-Till 2026. Asian Pac J Cancer Prev 14(7): 4379-4386.

12. Mummert H, Gradmann D (1999) Action potentials in Acetabularia: measurement and simulation of voltage-gated fluxes. J Membr Biol 124 (3): 265-273.

13. Callies C, Fels J, Liashkovich I, Kliche K, Jeggle P, et al. (2011) Membrane potential depolarization decreases the stiffness of vascular endothelial cells. J Cell Sci 124: 1936-1942.

Your next submission with Juniper Publishers
will reach you the below assets
- Quality Editorial service
- Swift Peer Review
- Reprints availability
- E-prints Service
- Manuscript Podcast for convenient understanding
- Global attainment for your research
- Manuscript accessibility in different formats
( Pdf, E-pub, Full Text, Audio)
- Unceasing customer service
Track the below URL for one-step submission
https://juniperpublishers.com/online-submission.php

